\title{
Profile of Congenital Hypothyroidism in DR. Cipto Mangunkusumo Hospital
}

\author{
Dana Nur Prihadi ${ }^{*}$, Frida Soesanti ${ }^{2}$, Aman B Pulungan ${ }^{2}$ Bambang Tridjaja ${ }^{2}$, Jose RL Batubara2 \\ Indonesia Pediatric Endocrinology working Group ${ }^{1}$
}

From 7th APPES Biennial Scientific Meeting

Nusa Dua, Bali. 14-17 November 2012

\section{Background}

Congenital Hypothyroidism $(\mathrm{CH})$ affects children from infant and results from a partial or complete loss of thyroid function. Unrecognized $\mathrm{CH}$ can make some problems in health of children.

\section{Method}

A retrospective study of congenital hypothyroidism in dr. Cipto Mangunkusumo Hospital, during January 2010-December 2011.

\section{Results}

There were 40 children with $\mathrm{CH}$ included in the study. Boys 12(30\%) and girls 28(70\%). Age when diagnosed 0-3 months 4(10\%), 3-6 months 2(5\%), 6-12 months 9 (22,5\%), 1-6 years $20(50 \%), 6-14$ years $5(12,5 \%)$. Clinical manifestation: delayed development $27,5 \%$, underweight $17,5 \%$, acute respiratory infection $15 \%$, constipation $12,5 \%$, hypotonia $7,5 \%$, speech delay $5 \%$, short stature $5 \%$, enlarged tongue $2,5 \%$, vomite $2,5 \%$, icteric $2,5 \%$, enlarged lymph node of colli $2,5 \%$. We found suspect down syndrome $4(10 \%)$, severe malnutrition $4(10 \%)$, short stature $3(7,5 \%)$, mental retardation $2(5 \%)$.

\section{Conclusion}

In our study, most common age of $\mathrm{CH}$ patients was 1-6 years, most sex was girls, which often founded were delayed development.

'Department of Paediatrics, Gatot Soebroto Central Army Hospital, Jakarta, Indonesia

Full list of author information is available at the end of the article

\section{Authors' details}

'Department of Paediatrics, Gatot Soebroto Central Army Hospital, Jakarta, Indonesia. ${ }^{2}$ Department of Paediatrics, School of Medicine, University of Indonesia, dr. Cipto Mangun Kusumo Hospital, Jakarta, Indonesia.

Published: 3 October 2013

doi:10.1186/1687-9856-2013-S1-P146

Cite this article as: Prihadi et al:: Profile of Congenital Hypothyroidism in DR. Cipto Mangunkusumo Hospital. International Journal of Pediatric Endocrinology 2013 2013(Suppl 1):P146.
Submit your next manuscript to BioMed Central and take full advantage of:

- Convenient online submission

- Thorough peer review

- No space constraints or color figure charges

- Immediate publication on acceptance

- Inclusion in PubMed, CAS, Scopus and Google Scholar

- Research which is freely available for redistribution

Submit your manuscript at www.biomedcentral.com/submit
() Biomed Central 